\title{
Corrigendum: Both respiration and photosynthesis determine the scaling of plankton metabolism in the oligotrophic ocean
}

Pablo Serret, Carol Robinson, María Aranguren-Gassis, Enma Elena García-Martín, Niki Gist, Vassilis Kitidis, José Lozano, John Stephens, Carolyn Harris \& Rob Thomas

Nature Communications 6:6961 doi: 10.1038/ncomms7961 (2015); Published 24 Apr 2015; Updated 15 Jun 2016

The original version of this Article failed to fully credit the use of the Ocean Data View software in figure 3, which appears below: Schlitzer, R., Ocean Data View, http://odv.awi.de, 2016.

(c) This work is licensed under a Creative Commons Attribution 4.0 International License. The images or other third party material in this article are included in the article's Creative Commons license, unless indicated otherwise in the credit line; if the material is not included under the Creative Comm
to obtain permission from the license holder to reproduce the material. To view a copy of this license, visit http://creativecommons.org/licenses/by/4.0/ 